University of Louisville

ThinkIR: The University of Louisville's Institutional Repository

\title{
$5-2013$
}

\section{An examination of interest groups : impact on public opinion.}

Olivia Feldkamp

University of Louisville

Follow this and additional works at: https://ir.library.louisville.edu/honors

Part of the American Politics Commons

\section{Recommended Citation}

Feldkamp, Olivia, "An examination of interest groups : impact on public opinion." (2013). College of Arts \& Sciences Senior Honors Theses. Paper 15.

http://doi.org/10.18297/honors/15

This Senior Honors Thesis is brought to you for free and open access by the College of Arts \& Sciences at ThinkIR: The University of Louisville's Institutional Repository. It has been accepted for inclusion in College of Arts \& Sciences Senior Honors Theses by an authorized administrator of ThinkIR: The University of Louisville's Institutional Repository. This title appears here courtesy of the author, who has retained all other copyrights. For more information, please contact thinkir@louisville.edu. 


\title{
An Examination of Interest Groups: \\ Impact on Public Opinion
}

\author{
By: \\ Olivia Feldkamp \\ Submitted in partial fulfillment of the requirements for Graduation \\ Summa Cum Laude \\ and \\ For Graduation with Honors from the Department of Political Science \\ and \\ For Graduation from the Honors Scholar Program \\ University of Louisville \\ May, 2013
}




\section{Introduction}

Interest groups in the United States play a central role in shaping debates over highly controversial issues such as same-sex marriage or anti-immigration laws. By creating a powerful interest group and attempting to exercise power through this group, political and ideological minorities try to shape public opinion and pressure policymakers to pass legislation on their behalf. These groups rely on the freedom of expression — a right of every American — to justify their goals and activities. Few citizens in the larger population question the right of groups to pursue, actively and aggressively, outcomes that serve their special interests. Regarding some topics, however, the majority opinion differs from the values and goals promoted by smaller, but powerful, interest groups. The relationship between these values and goals and those of the larger society, are often tapped into by public-opinion polls. Moreover, referenda are critical tools for measuring the success of interest groups in seeking legislation that not — at least initially — reflect the values of the wider community.

Some states, including California and Kentucky, periodically hold referenda to settle controversial policy issues. This allows citizens potentially to forego a process by which elected representatives legislate on behalf of citizens. Rather, citizens vote directly. In essence, representative democracy is temporarily suspended and replaced by direct democracy. The results, however, do not always align with the goals of the interest groups promoting such an approach and often reveal the central weakness in the direct-democracy approach to governance. This research aimed to determine to what extent interest groups have shaped public opinion within the past thirty years through two case studies focusing on the continuing same-sex marriage campaign and the debate on immigration, focusing on the campaign surrounding the referendum on Proposition 187. Do citizens respond to interest-group campaigns? If a response 
occurs, in which situations is the response immediate and in which is it a gradual shift? How effective are referenda for groups seeking to change policy without relying on representative democracy? What obstacles do interest groups confront?

\section{Literature Review}

The majority of existing literature on interest groups focuses on their power and ability to influence policy decisions. Interest Groups Unleashed, a study by Paul Herrnson, Christopher Deering, and Clyde Wilcox, focuses on the increased activity of interest groups in recent years and their expanding role in American politics. Another relevant study, Interest Groups in American Politics: Pressure and Power, by Anthony Nownes, examines the impact of interestgroup lobbying at all levels of political activities, both federally and on the state level. In addition, a few articles have focused on the obstacles facing interest groups and their inherent weakness in taking on some aspect of the mainstream culture. This study examines the challenges interest groups face in terms of shaping the policy preferences of the general public. My work, then, distinguishes itself because it concentrates not on the impact of interest groups on elected officials, but on the public at large.

Legislators typically respond to the grievances and demands of interest groups. Legislators need the vote and support of these groups because they tend to be the most active and powerful in supporting or undermining their re-election campaigns. Indeed, legislators tend to seek support of the vocal, motivated, active, and highly visible individuals in interest groups when setting out to raise funds and organize their continuing campaign efforts. Ultimately, as influential organizations are both receptors of information and significant "providers of 
important information," ${ }^{1}$ they gain more attention and elicit more response from elected officials than from individual citizens. This holds true even when their collective opinion may not support the values or goals of the majority. Indeed, one might say, "the squeaking wheel gets the grease."

On the other hand, citizens tend to be markedly less influenced by interest-group activities than are legislators. Most citizens do not participate in activist political organizations and typically feel neither pressure nor a need to respond to their grievances or demands. As one scholar argued, from the perspective of interest groups, predicting group behavior of response is difficult, "based on a muddied series of known and unknown variables."”

\section{Interest Groups}

Interest groups, as Binderkrantz defines them, are "membership organizations working to obtain political influence.”3 Members can be individuals, firms, governmental institutions, and even other interest groups. They are strategic actors with limited resources working to maximize the impact of their actions. ${ }^{4}$ Distinctions can be made between types of interest groups. Some, for example, are public interest groups, which define their goal as public or "collective" in nature. Others might be classified as "specialized" interest groups, which attract members who have a specific stake in the goal of the group. Generally, specialized groups do not appeal to

\footnotetext{
${ }^{1}$ Victor, Jennifer Nicoll. 2007. "Strategic Lobbying." American Politics Research. 35. no. 6 (2007), p. 828; see also Caldeira \& Wright, 1998; Hall \& Wayman, 1990; Hansen, 1991; Kingdon, 1989, Milbrath, 1963.

${ }^{2}$ Ibid., p. 828.

${ }^{3}$ Binderkrantz, Anne Skorkjaer. 2012. "Interest Groups in the Media: Bias and Diversity Over Time." European Journal of Political Research 51 (1), p. 119.

${ }^{4}$ Victor, p. 830.
} 
society as a whole. ${ }^{5}$ Some are more specific, while others are more general. This study examines a case study on both types of interest groups.

Methods used by interest groups include direct lobbying, or insider lobbying, defined as "close consultation with political and administrative leaders, relying mainly on financial resources, substantive expertise, and concentration within certain congressional constituencies as a basis for influence.” 6 This involves one-on-one contact and the exchange of information in order to influence legislators. ${ }^{7}$ This allows legislators to try to gauge "how constituents might react to certain policies” ${ }^{8}$ by turning to interest groups for the signposts necessary.

The second approach is indirect, or "outside," and involves lobbying tactics "aimed at influencing the views of the general public.” The ultimate goal, however, remains to "affect the preferences of legislators."9 This latter approach is generally used less - in politics the legislators matter more than citizens - because of its erratic and unpredictable results. Generally, this becomes more the approach of choice when "the level of importance ascribed to an issue on the agenda" typically increases. ${ }^{10}$ Indirect lobbying is the approach examined throughout this research through case studies regarding the controversy surrounding same-sex marriage and immigration to determine if and when indirect lobbying techniques are successful in swaying public opinion and what factors might be relevant in predicting or measuring success.

The literature reveals that interest-group activity is shaped by a wide array of variables. As one scholar contended, an interest group makes "strategic lobbying choices based on its available resources, its lobbying target, the characteristics of the issue, and the characteristics of

\footnotetext{
${ }^{5}$ Binderkrantz, p. 119; see also, Berry 1999; Scholozman 1984; Dunleavy 1988; Halpin 2006.

${ }^{6}$ Victor, p. 827. see also Gais \& Walker, p. 103.

${ }^{7}$ Victor, p. 827.

${ }^{8}$ Ibid., p. 828.

${ }^{9}$ Ibid., p. 827.

${ }^{10}$ Ibid., p. 831.
} 
other groups." ${ }^{11}$ However, interest groups must occasionally acknowledge that the public is not ready to accept some initiatives. Therefore, some groups are forced to table some issues for the overall benefit of their ultimate, overarching goal. For example, the "heavy hitters in the California gay legal movement" decided "not to pursue [same-sex] marriage litigation in California" to avoid a large push by anti-gay marriage advocates that would not be defeated. ${ }^{12}$ Interest groups have played a critical role in contributing to the heated debate regarding same-sex marriage and civil unions.

\section{Case Study: Same-Sex Marriage Activist Groups}

\section{Historical Background}

In the last three decades, most Western countries have passed legislation that has advanced the equal rights and protection for all citizens. ${ }^{13}$ In the United States, however, many homosexuals have argued that the level of rights and protection of same-sex partnerships remains wholly insufficient. For example, groups overwhelmingly argue that many state laws discriminate against same-sex partnerships by refusing to recognize same-sex marriage. The recent controversies over the legalization of same-sex marriages were spurred by an event that occurred in Hawaii in 1990. Three same-sex couples requested civil marriage licenses from the state of Hawaii but were denied. Their case eventually reached the Hawaii Supreme Court, which ruled that "the denial of marriage licenses to same-sex couples violated the state's

\footnotetext{
${ }^{11}$ Ibid., pp. 827-828.

${ }^{12}$ Hirshman, Linda. Victory: The Triumphant Gay Revolution. New York: Harper Collins Publishers. (2012), p. 302.

${ }^{13}$ MacIntosh, Heather, Elke D. Reissing, and Heather Andruff. "Same-Sex Marriage In Canada: The Impact Of Legal Marriage On The First Cohort Of Gay And Lesbian Canadians To Wed." Canadian Journal Of Human Sexuality. 19. no. 3 (2010), p. 79.
} 
constitutional guarantee of equal protection." ${ }^{14}$ This ruling distinguished Hawaii as the "first state in history to rule in favor of same-sex marriage."15

Despite this ruling, however, marriage has remained, according to some scholars, essentially immune from cultural pressures to conform to the broad ideas of the liberal state. ${ }^{16}$ By this, I mean that marriage has not traditionally been open to reform, and its principles have not been flexible. In fact, the concept of marriage in the United States is a Christian-based phenomenon that has been jealously guarded by primarily the Christian religious establishment. Indeed, "marriage has been largely immune from basic principles like separation of church and state" that differentiates it from other issues in our country and places it in the realm of "moral politics." ${ }^{\not 17}$ This inflexibility has triggered the response of gay-rights activist organizations.

On the federal level, the existing legislation on same-sex marriage occurred as a result of the previously mentioned Hawaii Supreme Court ruling. President Bill Clinton signed his legislation, the Defense of Marriage Act (DOMA), which codified marriage at the federal level as "exclusively heterosexual unions." ${ }^{\text {18 }}$ Consequently, it meant that states did not have to begin recognizing same-sex marriage in their own state or those same-sex marriages recognized by other states. Thirty-eight states echoed DOMA by passing constitutional amendments ensuring the protection of heterosexual marriage. California, for example, passed Proposition 8 by popular referenda during the 2008 lection. Proposition 8 implemented a constitutional amendment that banned the recognition of same-sex marriages in the state.

\footnotetext{
${ }^{14}$ Glass, Christy M., Nancy Kubasek, and Elizabeth Kiester. "Toward A 'European Model' of Same-Sex Marriage Rights: A Viable Pathway for the U.S.?." Berkeley Journal Of International Law 29. no. 1 (March 2011), p. 135.

${ }^{15}$ Hirshman, p. 233.

${ }^{16}$ Hirshman, p. 238.

17 Ibid., p. 239.

${ }^{18}$ Glass, p. 136.
} 
More recently in June 2006, a proposed federal constitutional amendment, the Federal Marriage Protection Act, broadly supported by President George W. Bush and aimed at banning same-sex marriages, failed to pass the Senate by a simple vote. While some states took steps to ban the recognition of same-sex marriages, since 2003 numerous states, including Massachusetts, Connecticut, and Iowa, have recognized same-sex marriages through judicial interpretations of state constitutions. Others, like Vermont, Maine, and New Hampshire, have recognized them through legislation. ${ }^{19}$ The broad diversity of responses from states regarding same-sex marriage, demonstrates the contentiousness of the topic.

\section{Basis of Support}

The support between the two sides of the same-sex marriage debate is typically divided by age group, religious beliefs and political-party identification. Younger voters are consistently more supportive of the Lesbian, Gay, Bisexual, and Transgender (LGBT) community than older ones. Approximately 62 percent of adults between the ages of 18 and 29 support gay marriage compared to 31 percent among those 65 years of age and older. ${ }^{20}$ The religious right, active churchgoers, and members of the Republican Party generally favor less the legalization of samesex marriages in the United States. Democrats, generally less religious with fewer citizens active in a church, tend to believe that "moral judgments should not affect governmental actions," because rights "to equality, to intimate association, [and] to privacy are more important." ${ }^{21}$ That is, Democrats generally argue that moral, in this case traditionally Christian values, must not

\footnotetext{
${ }^{19}$ Eskride Jr., William N. “The California Proposition 8 Case: What Is a Constitution For?.” California Law Review. 98. no. 4 (2010), p. 1236.

${ }^{20}$ Lollier, Travis. "Evangelical Churches Refine Message on Gay Issues." Associated Press Archive. (2013).

${ }^{21}$ Feldblum, Chai R. "Gay Rights." Nation. 271. no. 10 (2000), p. 22.
} 
shape policy-making decisions. Trends in support of or opposition to gay marriage have been linked to sex, race/ethnicity, region, size of place, and education level. ${ }^{22}$ Research shows that women, people living in urban areas, and the more educated tend to be more supportive, while men, those living in rural areas or small towns, African Americans, and southerners tend to be less supportive. $^{23}$

Of course, these trends are vague and general. For example, political-party affiliation, gender, and level of education are not always clear indications of an individual's stance on the legalization of same-sex marriages. The Log Cabin Republicans, an organization formed in the 1970s, and the GOProud Organization, for example, are gay-rights advocacy groups within the Republican Party. Additionally, during the 2009 presidential campaign, Senator John McCain’s senior campaign strategist, Steve Schmidt, delivered a widely covered speech endorsing gay marriage. $^{24}$

\section{Campaign}

Questions to be answered regarding the same-sex marriage debate include the following: How have interest groups shaped the battle over same-sex marriage in the United States? Who typically belongs to the interest groups representing each side of the same-sex marriage debate? What arguments are made, and how does each side address them? What strategies are used? Which interest groups in this debate respond to the arguments presented by the opposing side?

Some extreme and moderate groups exist on each side of the same-sex marriage debate, creating unique combinations of bedfellows joining together to both support and oppose gay

\footnotetext{
${ }^{22}$ Baunach, Dawn Michelle. "Decomposing Trends In Attitudes Toward Gay Marriage, 19882006." Social Science Quarterly (Blackwell Publishing Limited). 92. no. 2 (2011), p. 350-351.

${ }^{23}$ Baunach, p. 351.

${ }^{24}$ Kirchick, James. "Battle Of The Homocons." New Republic. 240. no. 8 (2009), p. 10.
} 
marriage. Extreme right-wing Christian groups and the more moderate National Organization For Marriage (NOM), for example, have worked together to prevent the legalization of same-sex marriage. Some opponents argue that same-sex marriage poses a "danger . . . to marriage."25 Other groups, such as the National Center for Lesbian Rights, the Human Rights Campaign, the Gay and Lesbian Activists Alliance, the Americans for Truth About Homosexuality, and the Gay and Lesbian Task Force fight for equal rights for the LGBT community. Fundamentally, activist groups for gay rights, including Equality for Gays and Lesbians Everywhere (Egale), argue that equal treatment is a fundamental right. They contend that "legal recognition of same-sex relationships [is] necessary to achieving equality."26

The first main argument against same-sex marriage is that the legalization of gay marriage will result in an increase in the number of homosexuals. Opponents argue that legalization of gay marriage will lead to more and more gay couples, which will slowly undermine traditional Christian culture in the U.S. Gay-rights activists respond by arguing that there appears to be more gay couples in states where gay marriage is legal because gays are more relaxed and open about their sexual preference. In so many states, gays remain "in the closet" afraid of making their true preferences known. In states where they feel protected, where tolerant peers surround them, they will be more open and straightforward. These gay policies, activists argue, do not create more homosexuality. Instead, they create policies where closeted gays can come out and make their presence felt. Moreover, gay-friendly policies attract gays from other states. The increase in the gay population is not necessarily credited to new individuals becoming gay, lesbian, bisexual, or transgender, but instead to an increased number

\footnotetext{
${ }^{25}$ Steved. "Disgusting: Anti-Gay Marriage Group’s Activist Sign Suggests Lynching SameSex Couples." AlterNet. N.p., 28 Jul 2010.

${ }^{26}$ MacIntosh, p. 79.
} 
of people disclosing their sexual orientation. There are organizations, like the Gay and Lesbian Task Force that encourage individuals to report if they are members of the LGBT community. Once gays are open and honest about their sexual preference, they are more likely to become active and responsive to the rights of their group.

Some anti-gay and lesbian activist groups believe that same-sex marriage will decrease and dishonor traditional marriage. Therefore, the second argument made to deter support is that “marriage (between heterosexuals) is a 'bedrock' institution, deserving of legislative protection.”27 More specifically, elements, like reproduction and proper care for children, are necessary to have a "true" marriage. After the legalization of gay marriage in Canada, the majority of the same-sex couples surveyed felt "more open to or ready for the idea of having children.”28 Many conservatives point to this reality as another reason for not supporting samesex marriages. Nontraditional family structures, they argue, can have a negative impact on children. Historically, women have "provided children with experiences and qualities men cannot, and vice versa."29 Because they seek to combat directly these issues, and defend their cause in response to these arguments, same-sex marriage advocates focus on the equal rights homosexual couples should have under the Constitution.

Finally, some arguments against homosexual marriages pertain specifically to religious belief. This contends that homosexuality is not the way in which God intended humans to interact. $^{30}$ In extreme instances, this is taken a step further and it is argued that anarchy will

\footnotetext{
${ }^{27}$ Edwards, Jane. "'Marriage Is Sacred': The Religious Right's Arguments Against 'Gay Marriage' In Australia." Culture, Health \& Sexuality. 9. no. 3 (2007), p. 248.

${ }^{28}$ Macintosh, p. 86.

${ }^{29}$ Edwards, p. 250.

${ }^{30}$ Adam, Barry D. "The Defense Of Marriage Act And American Exceptionalism: The "Gay Marriage" Panic In The United States." Journal Of The History Of Sexuality. 12. no. 2 (2003), p. 263.
} 
result from the re-definition of marriage. ${ }^{31}$ Since these arguments are based less on fact and more on individual values, gay-rights activists can do little to disprove this implication without appearing anti-religious or hostile to religious citizens. The debate here is fundamentally over the willingness of citizens to chip away at the long-standing tradition, the concept and institution of marriage. For the most part, activists are on the reactive side of the debate: they are pushed to respond to the broad defense of traditional marriage. This means same-sex marriage advocates fight an uphill battle to change public opinion.

In the case of the California proposition, the media, referencing news coverage, television programming, and advertisements throughout this study, has been a major influence. Television programming has become more accepting of same-sex marriage and thus contributed to the effort to create a gradual shift in the national mood. Groups on each side of the issue used the strategy of television advertisements, among other media sources, to reach homes. The media aims to push the boundaries of acceptance in order to excite and engage viewers. For this reason, the media, with the exception of conservative channels and news stations, focuses on less traditional and occasionally controversial topics. For example, in 1997, "network television star Ellen DeGeneres announced she was a lesbian” after being asked if she was coming out or not during the episode of her show that aired earlier that day. ${ }^{32}$ The character qualities given to gay characters in television programming have shifted. This has become increasingly evident, as homosexuality has been integrated into programming. When homosexual characters where first included in programming, they were typically assigned humorous and sometimes insulting roles. Currently, ABC has been airing the Emmy-winning show, Modern Family since 2009. This series presents same-sex marriage, the adoption of children by same-sex couples, remarriage, and

\footnotetext{
${ }^{31}$ Edwards, p. 254.

${ }^{32}$ Hirshman, p. 283.
} 
interracial marriage as everyday normal. This liberal view of marriage can potentially alter the opinions of those exposed to the show. Even the title of the series provides insight into what is acceptable or expected of family structure by modern or current standards. In addition to the television media, advocates for gay rights "moved quickly to adopt the new techniques . . . available ... in the Internet age."33

The campaign that occurred leading up to the 2008 vote on Proposition 8 in California provides insight into the importance of effective advertising, which in the current era, is connected both to the Internet and the television media. ProtectMarriage, a pro-Proposition 8 group, aired an ad called "Princes." This ad implied that children would be taught that instead of a princess and prince being married, a prince could marry a prince, which causes the young girl in the commercial to want to marry a princess. ${ }^{34}$ Polls revealed that parents with small children became largely more supportive of the proposition following the airing of this advertisement, despite the fact that gay marriage advocates ran ads with the superintendent of Public Education denying that the issue "had anything to do with public schools." ${ }^{35}$ This shows the impact the media can have on opinions. Despite the trend in positive support for same-sex marriage within television programming, the advertisements paid for by opponents had a larger impact on some voters. Once parents had begun to believe the "Princes" ad, there seemed to be no changing their minds, resulting in the passage of Proposition 8 against same-sex marriage in California.

\footnotetext{
33 Ibid., p. 284.

${ }^{34}$ Ibid., p. 306.

${ }^{35}$ Ibid., pp. 306-307.
} 


\section{Outcome and Analysis}

Compared to many industrialized countries that have "implemented some form of recognized partnership, either legally recognized civil unions or domestic partnerships,” the United States has made little progress in the realm of same-sex marriage rights. ${ }^{36}$ Twenty-eight states have little or no law that affirms any aspect of gay rights. ${ }^{37}$ This includes "no recognition of gay couples of any sort, no antidiscrimination laws or acknowledgment of bullying of gay kids in the schools.”38 However, it seems that those in favor of the legalization of gay marriage are increasingly more influential in the political and social community as time passes. ${ }^{39}$ While nearly 75 percent of Kentucky voters "voted in favor of a 2004 amendment to the state constitution affirming the traditional definition of marriage," 40 one national study shows that between 1988 and 2006 respondents who felt homosexual couples should not marry has fallen by almost 20 percentage points from 71.4 percent to 52.4 percent. $^{41}$ Additionally, some opinion polls have revealed that "a plurality or even a slight majority of Americans” marriage, and in 2012, “for the first time, the level of strong support for gay marriage is equal to the level of strong opposition."43

This could be credited to the Supreme Court's ruling against sodomy laws in $2003^{44}$ and the recent, positive portrayals of gay and lesbian relationships within media programming.

\footnotetext{
${ }^{36}$ Glass, p. 140.

${ }^{37}$ Hirshman, p. 343.

${ }^{38}$ Ibid.

${ }^{39}$ Ibid., p. 288.

40 Taranto, James. "Prematurely Gay." American Spectator. 45. No. 6 (2012), p. 60.

${ }^{41}$ Baunach, p. 354.

42 Taranto, p. 61.

43 "Opposition To Gay Marriage Lower In 2012 Campaign." Christian Century. 129. no. 11 (2012), p. 19.

${ }^{4}$ Baunach, p. 359.
} 
Specifically, the use of homosexual characters and supportive friends and families in television shows has made homosexuality a less taboo issue and has increased acceptance, especially among young voters who have been exposed to this nearly their whole lives.

Despite the passing of Proposition 8, in recent years, "the level of mutual toleration seems to have increased in the United States, so that those opposed to gay marriage are now more willing to adopt a live-and-let-live approach." ${ }^{45}$ This spurs an increase in support for the legalization of same-sex marriages, especially by the younger generation. The shift in national mood on this topic has even influenced Republican presidential candidates, proving that the issue is becoming decreasingly bipartisan. The shift has also signified progress in the same-sex marriage campaign that in the past has been a nearly hopeless fight against opponents who have been "wildly successful in mobilizing anti-marriage constituencies."46

For example, some of the strongest opponents, evangelical churches, have begun to alter their methods for addressing same-sex marriage as "mainstream support for gay and lesbian issues increases." ${ }^{47}$ One main cause for this increase in mainstream support could be credited to a change in "the framing of gay marriage." ${ }^{48}$ This is supported by the concept that "individuals do not merely respond to media discourse but actively engage it to generate their own beliefs" in conjunction with "their own personal experiences and learned cultural expectations." ${ }^{49}$ Two competing frameworks within the television media are "morality," used by those opposed to gay

\footnotetext{
${ }^{45}$ Esptein, Richard A. "The Constitutionality Of Proposition 8." Harvard Journal Of Law \& Public Policy. 34. no. 4 (2011), p. 881.

${ }^{46}$ Glass, p. 135.

${ }^{47}$ Lollier, Travis. 2013. "Evangelical Reform and Voter Turnout: A Review of the History.” Associated Press Archive.

${ }^{48}$ Baunach, p. 348.; see also Gamson.

${ }^{49}$ Ibid.
} 
marriage, and "equality or tolerance," used in support that "likens marriage (or civil unions) for gay men and lesbians to heterosexual marriage.”,

Shifts in attitude tend to occur either because of population changes, demographic shifts, or societal-level changes in individual opinion. ${ }^{51}$ Changes in attitude toward gay marriage seems to be a "cohort succession (as younger generations that have been exposed to different socializing experiences replace older generations) or intracohort change (as individuals change their minds about an issue, possibly in response to framing and cultural shifts).,

Regarding same-sex marriage, interest groups have helped to change national mood and public opinion even within the last several years it seems, when considering that in 2008 California passed a constitutional amendment against same-sex marriage, and now "61 percent of Californians now approve of allowing same-sex couples to marry."53 This could be an example of referenda not being truly representative of the entire population, or an example of a rapid shift in public opinion. This shift has occurred with the help of the media and the fact that citizens are experiencing more connections with the LGBT community as the number of individuals disclosing their sexual orientation has increased. ${ }^{54}$ Scholars believe that "acceptance of gay marriage is likely to continue to grow, and with that, laws are likely to change.”

\section{Referenda}

Referenda played a role in setbacks in the same-sex marriage campaign by reversing the Hawaii Supreme Court ruling and the victory advocates experienced in Alaska during the earlier

\footnotetext{
${ }^{50}$ Baunach, p. 348.

51 Ibid., pp. 349-350.

52 Ibid., p. 350.
}

53 _. "Poll: Calif. Support of Gay Marriage at 61 Percent." 2013. Associated Press Archieve.

${ }^{54}$ Lollier 
years of the campaign. ${ }^{55}$ Conducting a referendum is clearly a way to gauge voter opinion and to "toss the issue[s] to the people," ${ }^{56}$ but it can also be a way to determine interest groups impact on public opinion. Some do not hold a favorable view of referenda. Congressional use of referenda can be seen as a way to continue "a long history of buck-passing and issue-dodging.,57 Additionally, as a formal representative democracy instead of a direct democracy, referenda voting can virtually result in an opinion poll instead of action. Arguably, referenda appears to force elected officials to act upon the wishes of the United States people, which is the purpose of a representative democracy. But this is not always the case. Just as Congress is not required to act upon the results of opinion polls, legislators are not required to react to non-binding referenda. The use of wide-scale referenda on a national level would change the nature of Congressional action. It is important to highlight that many state referenda are binding, which places the power with the people, but allows policymakers to avoid implementing or taking important steps to operationalize the results.

Throughout American history, particularly during the Progressive era, calls for direct democracy initiatives have occurred. According to advocates of referenda and other direct democracy initiatives, the power of special interests would decrease and the "input of ordinary citizens" would increase through the use of referenda ${ }^{58}$ However, voter turnout for elections is consistently low, 41 percent of those eligible actually voted in the last election, ${ }^{59}$ and turnout is also unrepresentative in the United States. A 1980 study, Who Votes?, concluded that "Voters are not a microcosm of the entire body of citizens, but a distorted sample that exaggerates the

\footnotetext{
${ }^{55}$ Hirshman, p. 290.

56 Ibid.

57 __. "No National Referenda, Thanks.” The Washington Times. June 2013. A21.

${ }^{58}$ Munoz

${ }^{59}$ McGrath, Michael. "Election Reform and Voter Turnout: A Review of the History." National Civic Review. 101, no. 3 (2012), p. 38.
} 
size of some groups and minimizes that of others." ${ }^{\circ 0}$ Many groups within the population have a lower probability of voting than other groups, creating skewed representation; some groups “exert only half the voting strength” they should proportionally, and “electoral power of other groups is inflated by more than 25 percent." ${ }^{61}$ The likelihood of an individual to vote can be determined by age, income and education level, race and ethnicity, as “young people, lowerincome voters, less well educated citizens, and members of certain racial and ethnic minorities are substantially less likely to vote than older, white, and more affluent Americans.”62

The discrepancy between voter turnout and the makeup of the general population reveals that decreasing the influence of interest-group is an unlikely result of referenda. Traditionally, less powerful social groups, including those "more socially isolated and [those] less familiar with the workings of government, "63 do not vote. Predictably, politically active individuals like those who would be members of interest groups cast their votes more frequently.

Referenda could be seen as a lesser of two evils in comparison to special interest influence over Congressional leaders. Since the United States is a representative democracy, interest groups and politically active citizens hold more influence with elected officials on issues because of the legislators' desire for reelection. Referenda appear to take the power from Congressional leaders, potentially allowing minority groups who are unlikely to receive attention from these leaders, to have an impact on specific issues, because they are continuously outresourced by interest groups and PACs. Since social, racial, and ethnic minorities tend to be less politically aware, however, they are still less likely to vote in a referendum. Therefore, this

\footnotetext{
${ }^{60}$ McGrath, p. 38.

${ }^{61}$ McGrath, p. 38.; see also, Wolfinger, Raymond E., and Steven J. Rosenstone. Who votes? New Haven: Yale University Press. (1980), p. 108.

${ }^{62}$ McGrath, p. 38.

${ }^{63}$ McGrath, p. 38.
} 
benefit of referendum is neutralized accept when considering the possibility that minorities might vote on issues directly beneficial to them.

Statistics from the 2012 presidential election, however, show an increase in voter turnout and awareness. Compared to the 2008 election, more young voters, ages 18 to 29, voted in the most recent presidential election. This increase in young voter turnout has been credited by scholars and observes, in large part, to Generation Opportunity, the "largest non-profit, nonpartisan 501 organization in the United States," focused on "engaging and mobilizing 18-29 year olds on important economic issues." ${ }^{\prime 4}$ The organization's use of advanced social media tactics seems to be the most influential factor in their campaign for increased awareness. The ease of accessing information could very well contribute to continuous increases in voter turnout. This could even trigger a renewed focus on an effort to eliminate the Electoral College and increase support for referenda. As information becomes increasingly accessible, the need for the more educated elites to dominate American politics could decrease. Diversity within news coverage has been increasing, ${ }^{65}$ and therefore, the diversity of thought and information available to the public is increasing along with the sheer number of devices with Internet capabilities.

Furthermore, because referenda must be offered in the form of yes or no questions, those who oppose the use of referenda believe the results can be skewed through the wording of the question. The way a question is framed or phrased can alter the response given. This lays claim to the argument that those posing the questions, usually Congress when referring to referendum, would still hold the power. Also, political questions are consistently more complex than a yes or a no answer. Voters could agree with some aspects of each side of a political debate and be

\footnotetext{
${ }^{64}$ Ibid.

${ }^{65}$ Binderkrantz, Anne Skorkjaer. "Interest Groups in the Media: Bias and Diversity Over Time." European Journal of Political Research. 51. no. 1 (2012), p. 136.
} 
unable to convey this, since votes are pigeonholed. For example, Congress was surprised at the negative backlash from repealing the “Don’t Ask, Don’t Tell” policy in regards to gay members of the military, because of 67 percent approval rate of gay military service. ${ }^{66}$ Clearly, the complexity of the issue was not taken into account when interpreting the approval rate. Individuals could respond to a survey as approving of gay military service, while still believing the soldier should keep their sexual identification as a private matter. Yes and no questions prevent respondents from making this distinction.

While presidential elections occurring through popular vote seem to be a realistic possibility, a direct-democracy approach in the United States would not be feasible. Therefore, the role of the referendum as the mechanism of choice by activist groups will not likely increase in the years to come. It will remain, rather, a limited tool that will be utilized in special and infrequent circumstances.

\section{Case Study: Proposition 187}

\section{Historical Background}

Since the 1980s, the issue of immigration has become "increasingly politicized" ${ }^{\prime 67}$ in both Western Europe and the United States. This has been attributed to psychological and sociological variables, and economic self-interest. ${ }^{68}$ Research indicates that within the United States, statistically, the majority of Americans slightly oppose immigration. This could be

\footnotetext{
${ }^{66}$ Hirshman, p. 332.

${ }^{67}$ Fetzer, Joel S. "Economic Self-Interest Or Cultural Marginality? Anti-Immigration Sentiment And Nativist Political Movements In France, Germany And The USA." Journal Of Ethnic \& Migration Studies. 26. no. 1 (2000), p. 5.

${ }^{68}$ Ibid., pp. 5-6.
} 
caused by recent increases in immigration, ${ }^{69}$ the effects of the long-enduring economic crisis, a tendency to link, increasingly, crime with immigrants, a growing view that the U.S. is getting to crowded, or some combination of these explanations and others. Evidence shows that the majority of the immigrant population in the United States has entered the country since 1980, and as of 1995, 700,000 documented and 300,000 illegal immigrants enter the United States each year. ${ }^{70}$ In California specifically, 250,000 immigrants settle each year, and 45 percent of the 7.5 million Latinos in California are immigrants. ${ }^{71}$ Estimates have revealed that California hosted more than 40 percent of all illegal immigrants in the United States. ${ }^{72}$ The number has continually fallen because the immigrant population is a bit more dispersed today. But generally, taxpayers are frustrated at the government's inability to control immigration. ${ }^{73}$ Others complain that immigration policy is enforced sporadically and inconsistently. According to some scholars, the federal government has acted "to protect Florida from waves of immigrants ... [and] beefed up the Border Patrol in Texas,” while taking little to no action in California. ${ }^{74}$ Additionally, since 1994, California has endured continuing economic crisis, and a traditionally left-of-center state citizens receive more welfare resources than in other states. ${ }^{75}$

${ }_{70}^{69}$ Ibid., p. 13.

${ }^{70}$ Hovey, Joseph D., Rebecca S. Rojas Craig Kain, and Cristina Magana. "Proposition 187 Reexamined:.Attitudes Toward Immigration Among California Voters. (Cover Story)." Current Psychology. 19. no. 3 (2000), p. 169.

${ }^{71}$ Hovey, p. 169.

72 Elias, Thomas D. 1994. "Potent Issues on Ballot.” Press-Telegram (Long Beach, CA), Al.

${ }^{73}$ Saunders, Debra. 1994. "SOS Initiative is a Wake-Up Call.” Daily News of Los Angeles (CA). N15.

${ }^{74}$ Ibid.

${ }^{75}$ Hovey, p. 160.; see also Hondagneu-Sotelo; Johnson 


\section{Referendum}

Proposition 187, known as the "Save Our State” initiative, was brought to a vote in California in 1994 and took a harsh stance on immigration. Provisions included banning the children of illegal immigrants from enrollment in public schools and colleges, denying nonemergency public health care, and cutting-off social welfare services, including food stamps, unemployment insurance, and child welfare payments, for undocumented immigrants and their children. ${ }^{76}$ In addition, the proposition "created new state felonies and stiffer penalties for the use of fraudulent documents” and required workers of state and local agencies to report suspected illegal immigrants to the Immigration and Naturalization Service. ${ }^{77}$

\section{Basis of Support}

In 2000 only one study had been conducted regarding the correlation between specific personal characteristics and support of Proposition 187. This study revealed that Anglos "were significantly more in favor of Proposition 187 than were Latinos/as,” and found linkages between "right-wing authoritarianism and negative stereotypes about undocumented immigrants" and support of the Proposition. In regard to the Hispanic populations, support was linked to low self-esteem and high levels of assimilation into American culture, while support was linked to high self-esteem among Anglos. ${ }^{78}$

Another more general study indicated that those who are "middle-aged or older, less educated, and indentified as Republican were more likely to hold negative attitudes toward immigration.” In contrast, "students and individuals working in managerial or professional

\footnotetext{
${ }^{76}$ Elias.

${ }^{77}$ Hovey, p. 159.

${ }^{78}$ Hovey, p. 161.
} 
positions" were more likely to hold positive attitudes than those "working in other jobs and those who were unemployed."79 Additionally, those with a more recent family history of immigration, from any country, looked upon immigration more favorably. Media advertisements are also cited as a large contributor to negative attitudes toward immigration and specific ethnic and racial groups. ${ }^{80}$ These findings and natural intuition support the conclusion that prejudice and a lack of interaction with immigrant populations is a likely indicator of anti-immigration sentiments. Perhaps predictably, those with a personal connection to or involvement with immigrants look more favorably upon immigration. Age, education level and political ideology also influence an individual's stance on immigration.

\section{Campaign}

Even Eugene McCarthy, a Democrat, and then presidential hopeful, saw Proposition 187 as an opportunity for a "test case" for handling immigration reforms as voters became increasingly "frustrated with no-results government." ${ }^{81}$ The first argument of advocates in favor of this initiative was that "undocumented immigrants hurt the state economy," and California's reputation as "the welfare state" encouraged illegal immigrants to seek residence in the state. ${ }^{82}$ The second argument cited undocumented immigrants as the cause for crowded classrooms and the downturn in the public education system. Debatably, the most extreme pro-Proposition 187 testament, the third, argued immigrants were failing to assimilate into mainstream culture and possessed cultural characteristics that would never be compatible with American society. ${ }^{83}$

\footnotetext{
${ }^{79}$ Ibid., p. 170.

${ }^{80}$ Ibid., p. 171.

${ }^{81}$ Saunders

${ }^{82}$ Hovey, p. 160.

${ }^{83}$ Ibid.
} 
Backers of Proposition 187 "ran inflammatory ads showing teams of shadowy figures” entering the United States from Mexico, and television programming associated Latino immigrants with "imagery of disease, invasion, and savagery." ${ }^{, 4}$ As the media created these connections for the public, it became easier to bias non-immigrant groups against this minority.

Despite the efforts of advocates and the negative imagery from the media, the issues surrounding Proposition 187 came under intense debate. Significantly, the California School Boards Association opposed Proposition 187 on the grounds that it was in stark contrast to their role as educators. Police officers joined educators, physicians, nurses and business leaders against the "Save Our State" initiative at events organized by Taxpayers Against 187. Critics alleged that the proposition used undocumented immigrates as scapegoats for the poor economy in the state, which is a trend throughout the history of anti-immigration legislations, and that immigrants actually contribute positively to the economy. ${ }^{85}$ Those against Proposition 187 worked to highlight the difficulty in determining immigration status. Furthermore, the reasons for suspecting an individual of being illegal and the requirements associated with state and local officials reporting suspected undocumented individuals were unclear. For these reasons, "it sanctioned discrimination” of Hispanics, and was, therefore, unjust. ${ }^{86}$

To fight against this discrimination, "Democratic elected officials and labor leaders assembled a statewide campaign committee,” the aforementioned Taxpayers Against 187, which gained the support of Woodward and McDowell, a prominent political consulting firm headed by two Republican strategists. ${ }^{87}$ This acquisition was essential in trying to develop strategy to "win

\footnotetext{
${ }^{84}$ Hosang, Daniel Martinez. "Lessons from the California Ballot." Social Policy. 41. no. 3 (2011), p. 21. 
the votes of white, suburban, and moderate voters. ${ }^{88}$ Interestingly, workers from grassroots and immigrant-rights organizations, including the Northern California Coalition for Immigrant and Refugee Rights, were largely excluded from the campaign strategy. Additionally, the campaign took a harsh stance on immigration in hopes of appealing to voters' desire "to do something (anything) to address" illegal immigration. ${ }^{89}$ The campaign included memos stating:

"Something must be done to stop the flow of illegal immigrants coming across the border. ... Illegal Immigration is a real problem, but Proposition 187 is not a real solution. ... [Proposition 187] won't result in their deportation. ... Every day, hundreds of thousands of undocumented workers handle our food supply in the fields and restaurants. Denying them basic health care would only spread communicable diseases throughout our communities and place us all at risk. ... Illegal immigration is illegal. Isn’t it time we enforce the law?"90

This harsh approach taken, aimed solely at winning the majority vote on Election Day, caused many immigrant-rights activists to not support the campaign set forth by the Taxpayers Against 187. An immigrant-rights attorney was quoted, “There’s absolutely no way we're going to sign off on this," being it "inconceivable to try to defeat a measure attacking immigrants by joining the attacks." ${ }^{91}$ This led most immigrant-rights groups to take a conflicting approach, battling the racism tied to the proposition, under the title of Californians United Against

\footnotetext{
${ }^{88}$ Ibid.

${ }^{89}$ Ibid.

${ }^{90}$ Hosang, p. 21.

${ }^{91}$ Ibid., p. 22.
} 
Proposition $187 .{ }^{92}$ The conflicts between the two campaigns, did not aid the progress of either group or the overall anti-Proposition 187 message.

\section{Outcome}

Despite the millions of dollars funneled into the campaign of Taxpayer Against 187 and the efforts of Californians United Against Proposition 187, 59 percent of California voters cast their vote in favor of the initiative. After the passage of California's Proposition 187, despite the fact that the proposition had been "blocked from enforcement since the day of its passage by injunctions issued by federal judges,"93 minority leaders worked to combat "assaults on immigrant rights and affirmative action." ${ }^{94}$ This continued action was needed, because following the passage of the referendum, acts of prejudice occurred throughout California and "utilization rates of both health and mental health clinic decreased." ${ }^{95}$ For example, in one instance a customer threatened a Latino cook with citizen's arrest unless he was able to produce a green card. In another example of discrimination, a pharmacist denied a prescription to a regular customer who was unable to produce on-the-spot evidence of citizenship. ${ }^{96}$

In 1997 U.S. District Judge Mariana Pfaelzer declared Proposition 187 unconstitutional. ${ }^{97}$ She argued that "it infringes on the constitutional prerogative of the federal government to regulate immigration ... since the 'power to regulate immigration is unquestionably exclusively

\footnotetext{
92 Ibid.

93 __. "Federal Judge Mariana Pfaelzer Will Formally Invalidate California Prop 187.” 1997. Human Events 53. No. 45:6.

${ }^{94}$ Fetzer, p. 18.

${ }^{95}$ Hovey, p. 169.

${ }^{96}$ Ibid.

${ }^{97}$ Ibid., p. 161.
} 
a federal power,' any state statute that regulates immigration is 'constitutionally proscribed.'"'98 The California Governor, Republican Pete Wilson, prohibited state appeals against the ruling. From the beginning, the governor had acknowledged that "parts of Proposition 187 clearly contradicted Supreme Court decisions, "99 but felt it would force reevaluation. After the proposition was declared unconstitutional, the aforementioned health clinic utilization rates "returned to baseline," demonstrating a clear connection between the utilization of and access to health care and the anti-immigration legislation.

\section{Analysis}

Analysis of immigration sentiment would suggest that "immigrant-rights activists . . . might contribute immeasurably [to combating nativism] by dispelling popular misconceptions about immigrants and immigration,"100 but the passage of Proposition 187 seems to combat this notion. Californians United Against Proposition 187 made this its goal, but was unsuccessful without positive media influence and Taxpayers Against 187's support. Those leading the Taxpayers Against 187’s campaign acknowledged, “it was fruitless to challenge voters’ beliefs,” because “you can’t change that.”"101 The focus was placed on proving that Proposition 187 did nothing to fix the problem. ${ }^{102}$ This supports the notion that an individual's support is based largely on personal character traits and past experiences, not the influence of interest groups. A campaign that even adopted this theory and worked to appeal to voter beliefs was unable to convince a large enough percentage of voters that the side of the issue they identify with the

\footnotetext{
98 “Federal Judge Mariana Pfaelzer Will Formally Invalidate California Prop 187.”

${ }^{99}$ Elias.

${ }^{100}$ Fetzer, p. 18.

${ }^{101}$ Hosang, p. 21.

102 Ibid.
} 
most was invalid. Ultimately, the majority of voters remained in favor of Proposition 187, which is consistent with the fact that early polls showed "the initiative favored by a 2-1 margin among the one-third of Californians who know about it."103

\section{Power of Media Influence}

Through this analysis, it has become evident that independent television programming and advertising by advocacy groups play a large role in the success and failure of a campaign. Research has revealed "Mediatisation"104 as a highly influential aspect of contemporary politics. This refers to the fact that "most citizens learn about politics from the media, and parties and politicians try to reach voters almost exclusively through the mass media."105 This pushes “interest groups to focus extensively on making a prominent media presence,"106 through advertisements, partnerships, and the staging of events that would be deemed coverage-worthy in order to run successful campaigns. It is a challenge for many less prominent organizations to obtain news coverage, because of a lack of "established positions in a political system" and the fact that "some issue areas attract more media attention than others."107 The fact that "the more active a group is in targeting decision makers directly, the more active it is in the media arena”108 implies that interest groups rely heavily on the media to help influence elected officials and the public. As sources point out, many news sources "long ago gave up any pretense of delivering

\footnotetext{
103 Elias.

${ }^{104}$ Binderkrantz, p. 117.

105 Binderkrantz, p. 117.; see also Binderkrantz \& Green-Pedersen; Kepplinger; and Mazzoleni \& Schulz 1991.

106 Binderkrantz, p. 117.

107 Ibid., p. 118.

108 Ibid., p. 121.
} 
straight news," ${ }^{109}$ so a network’s framing of the news is one of the main tools used by interest groups to shape public opinion.

In some situations, it is challenging to sway public opinion, however, because of the personal experiences and characteristics of each individual. Support for both same-sex marriage and anti-immigration legislation revealed trends in character traits and experiences of those generally on each side of the issue. People typically associate themselves with and embrace the goals of groups based on "involuntary associations." tended to form a pattern based on age, education level, typical political party affiliation, and personal experiences with LGBT individuals and immigrants, respectively. There are, of course, exceptions to the pattern, but it is important to point out the fact that character traits can define which side of an issue individuals will support. By identifying the groups most likely to already support their cause interest groups are able to target specific populations who would not typically identify with the groups’ cause but could potentially be swayed.

For example, same-sex marriage advocates focused largely on appealing to younger generations and urging religious moderates to support their cause, while anti-Proposition 187 organizations worked to sway Anglos, since they are more likely to support anti-immigration legislation. Research conducted regarding attitude changes in reference to same-sex marriage has shown that, in most cases, the attitudes of the demographic groups that are traditionally the most supportive were also the ones most likely to change. ${ }^{111}$ This could imply that most individuals who are members of traditionally non-supportive groups rarely change their opinions,

109 Taranto, p. 60.

${ }^{110}$ Beckley, Harlan. "Empowering Groups and Respect for Individual Dignity: A Review of Michael Walzer’s Politics and Passion.” Political Theology 7, no. 1 (2006), p. 12; see also, James M, Gustafson's account of "consent" to religious traditions, p.231-35.

${ }^{111}$ Baunach, p. 358. 
despite the fact that opinion change by individuals has contributed the most to the increased approval of gay marriage. ${ }^{112}$ This supports a theory that interest groups do not necessarily change the opinions of the general public but instead motivate those with similar opinions become more vocal and active when their target issue is a hot topic.

\section{Conclusion}

In conjunction with an individual's personal characteristics and experiences, the ultimate influence on public opinion is the media, referring to news coverage, television programming, and advertisements. When seeking policy change, especially change that challenges ingrained social traditions, it is difficult for interest groups to combat the opinions of individuals unless the media provides support for their cause. This is because individuals tend to identify with the policy option most in line with their personal feelings, and personal feelings are nearly impossible to alter. Arguably, if an interest group gets enough news coverage and programming attention, however, their support base could increase, because studies have shown that individuals internalize concepts presented by the media as their own opinions over time. The shift in support for same-sex marriage has occurred because of the increasingly positive portrayal of same-sex couples within television programming. On the other hand, Proposition 187 passed, in part, because of the negative imagery of immigrants presented by media programming, but more specifically, advertisements. In other words, the side with the most successful advertisement campaign typically gains immediate support, and special interests with programming support seem to obtain more gradual support.

${ }^{112}$ Ibid., p. 359. 
Citizens who remain politically inactive typically respond to interest-group campaigns when the media plays a role in that campaign. For these citizens to be aware of any interestgroup, news coverage is nearly essential; for public support of a special interest to increase, positive portrayals of that stance needs to be present in the media. Similarly, referenda are beneficial to interest-groups when advertising is used affectively. This is because campaigns aimed to impact referenda results need to quickly gain support compared to the gradual shift in public opinion that occurs through programming support.

This study also revealed obstacles faced by interest-groups. These obstacles include the preexisting beliefs, defining character traits, and experiences of individuals. It is nearly impossible to alter the core beliefs of individuals. In both case-studies, research has shown that demographics can generally predict which side of an issue individuals will support, and the media is one of the only easily accessible tactics to alter personal opinions. Additionally, interest-groups are challenged by successful advertising campaigns by the opposing side. The adverting used by the opponents of same-sex marriage before the referendum on Proposition 8 and that of anti-immigrant groups leading to the vote on Proposition 187 were highly successful in quickly influencing groups of the general public and both successfully led to the passage of the propositions. Those on the opposite side of these two issues were unable to quickly combat the advertising success. In the end, it seems clear that the media, more than any other social or political institution, is the most important factor in shaping the preferences and opinions of citizens. 


\section{Bibliography}

Adam, Barry D. "The Defense Of Marriage Act And American Exceptionalism: The "Gay Marriage" Panic In The United States." Journal Of The History Of Sexuality. 12. no. 2 (2003): 259-276.

Baunach, Dawn Michelle. "Decomposing Trends In Attitudes Toward Gay Marriage, 19882006." Social Science Quarterly (Blackwell Publishing Limited). 92. no. 2 (2011): 346363.

Beckley, Harlan. "Empowering Groups and Respect for Individual Dignity: A Review of Michael Walzer’s Politics and Passion.” Political Theology 7, no. 1 (2006): 11-28.

Binderkrantz, Anne Skorkjaer. "Interest Groups in the Media: Bias and Diversity Over Time." European Journal of Political Research. 51. no. 1 (2012): 117-139.

Binderkrantz, A.S. \& Green-Pedersen, C. "Policy or Processes in Focus?.” International Journal of Press/Politics. 14. no. 2. (2009): 166-185.

Caldeira, G. A., \& Wright, J. R. "Lobbying for justice: Organized interests, Supreme Court nominations, and United States Senate.” American Journal of Political Science. 82 (1998): 1109-1127.

Case, Kim, and Briana Stewart. "Heterosexual Privilege Awareness, Prejudice, And Support Of Gay Marriage Among Diversity Course Students." College Teaching. 58. no. 1 (2010): 37.

Dunleavy, P. "Democracy, Bureaucracy and Public Choice: Economic Explanations in Political Science.” New York: Harvester/Wheatsheaf. Z (1991).

"Editors' Note: Barbara Loomis And William N. Bonds." Journal Of The History Of Sexuality. 13. no. 4 (2004): 401.

Edwards, Jane. "'Marriage Is Sacred': The Religious Right's Arguments Against 'Gay Marriage' In Australia." Culture, Health \& Sexuality. 9. no. 3 (2007): 247-261.

Elias, Thomas D. 1994. "Potent Issues on Ballot." Press-Telegram (Long Beach, CA), A1.

Eskridge Jr., William N. "The California Proposition 8 Case: What Is A Constitution For?." California Law Review. 98. no. 4 (2010): 1235-1252.

Esptein, Richard A. "The Constitutionality Of Proposition 8." Harvard Journal Of Law \& Public Policy. 34. no. 4 (2011): 879-888.

__ . "Federal Judge Mariana Pfaelzer Will Formally Invalidate California Prop 187." 1997. Human Events 53. no. 45: 6. 
Feldblum, Chai R. "Gay Rights." Nation. 271. no. 10 (2000): 22-25.

Fetzer, Joel S. "Economic Self-Interest Or Cultural Marginality? Anti-Immigration Sentiment And Nativist Political Movements In France, Germany And The USA." Journal Of Ethnic \& Migration Studies. 26. no. 1 (2000): 5-23.

Gais, T. L., \& Walker, J. L., Jr. (1991). "Pathways to Influence in American Politics.” In J. L. Walker, Jr. (Ed.), Mobilizing interest groups in America. J. L. Walker, Jr. Ann Arbor: University of Michigan Press. (1991): 103-121.

Gamson, William A. “Talking Politics.” Cambridge: Cambridge University Press. (1992).

Generation Opportunity Matthew Faraci, 202-997-1636 EMAIL or, David Pasch. 2012. "2012 Presidential Election Study: Young Adults make Unexpected Choice." Business Wire.

Glass, Christy M., Nancy Kubasek, and Elizabeth Kiester. "Toward A 'European Model' of Same-Sex Marriage Rights: A Viable Pathway for the U.S.?." Berkeley Journal Of International Law 29. no. 1 (March 2011): 132-174.

Gustafson,J. M. “Ethics From a Theocentric Perspective.” Theology and Ethics. 1. Chicigo: University of Chicago Press. (1981).

Hall, R. L., \& Wayman, F. W. "Buying time: Moneyed interests and the mobilization of bias in congressional committees.” American Political Science Review, 84. (1990): 797-820.

Halpin, D. "The Participatory and Democratic Potential and Practice of Interest Groups: Between Solidarity and Representation. Public Administration. 84. no. 4. (2006): 919-940.

Hansen, J. M. “Gaining access: Congress and the farm lobby, 1919-1981.” Chicago: University of Chicago Press. (1991).

Hayes, Danny, and Matt Guardino. "The Influence Of Foreign Voices On U.S. Public Opinion." American Journal Of Political Science. 55. no. 4 (2011): 831-851.

Hirshman, Linda. Victory: The Triumphant Gay Revolution. New York: Harper Collins Publishers. (2012).

Hondagneu-Sotelo, P. “Unpacking 187: Targeting Mejicanas.” Immigration and ethnic communities: A focus on Latinos. R. I. Refugo. East Lansing, MI: Julian Samora Research Institute. (1986): 93-103.

Hosang, Daniel Martinez. "Lessons from the California Ballot." Social Policy. 41. no. 3 (2011): 20-24. 
Hovey, Joseph D., Rebecca S. Rojas Craig Kain, and Cristina Magana. "Proposition 187 Reexamined:.Attitudes Toward Immigration Among California Voters. (Cover Story)." Current Psychology. 19. no. 3 (2000): 159.

- Immigration: What Changes Should be Made in United States Immigration Policy?. Washington, D.C.: U.S. Government Printing Office. (1994).

Jamie Beckett, Chronicle South,Bay Bureau. 1994. "Law Officers Voice Objection to Prop. 187." The San Francisco Chronicle, A17.

John Rofe'. 1994. "L.A. Mayor: Economy Needs Work." Daily Breeze (Torrance, CA), A3.

Johnson, Gene. 2012. "Strategy, Timing Key to States' Pot Legalization." Associated Press Archive.

Johnson, K. Proposition 187: The Nativist Campaign, the Impact on the Latino Community, and the Future. (Research Rep. No. 15). East Lansing: Julian Samora Research Institute. (1996).

Kepplinger, H.M. Mediatization of Politics: Theory and Data. Journal of Communication. 52 no. 4 (2002): 972-986.

Kingdon, J. W. “Congressmen’s Voting Decisions.” Ann Arbor: University of Michigan Press. 3. (1989).

Kirchick, James. "Battle Of The Homocons." New Republic. 240. no. 8 (2009): 9-10.

LeMay, Michael. Illegal Immigration. Santa Barbara: Contemporary World Issues. (2007).

Lewis, Justin. Constructing Public Opinion: How Political Elites Do What They Like and Why We Seem to Go Along with It. New York: Columbia University Press, 2001.

Lollier, Travis. 2013. "Evangelical Churches Refine Message on Gay Issues." Associated Press Archive.

McGrath, Michael. "Election Reform and Voter Turnout: A Review of the History." National Civic Review. 101, no. 3 (2012): 38-43.

MacIntosh, Heather, Elke D. Reissing, and Heather Andruff. "Same-Sex Marriage In Canada: The Impact Of Legal Marriage On The First Cohort Of Gay And Lesbian Canadians To Wed." Canadian Journal Of Human Sexuality. 19. no. 3 (2010): 79-90.

Mazzoleni, G. \& Schulz, W. “'Mediatization’ of Politics: A Challenge for Democracy?” Political Communication. 16. no. 3 (1999): 247-261.

Milbrath, L. W. “The Washington lobbyists.” Chicago: Rand McNally. (1963). 
Munoz, V. Phillip. 1995. "No National Referenda, Thanks." The Washington Times, June 13, A21.

Ono, Kent A, and John M. Sloop. Shifting Borders: Rhetoric, Immigration, and California's Proposition 187. Philadelphia Pa.: Temple University Press, 2002.

"Opposition To Gay Marriage Lower In 2012 Campaign." Christian Century. 129. no. 11 (2012): 19.

—. "Poll: Calif. Support of Gay Marriage at 61 Percent." 2013.Associated Press Archive.

Saunders, Debra. 1994. "SOS Initiative is a Wake-Up Call." Daily News of Los Angeles (CA), N15.

Schlozman, K.L. "What Accent the Heavenly Chorus? Political Equality and the American Pressure System.” Journal of Politics. 46. no. 4 (1984): 1006-1032.

Stacey, Judith. Unhitched: Love, Marriage, and Family Values from West Hollywood to Western China. New York: New York University Press, 2011.

Steved. "Disgusting: Anti-Gay Marriage Group’s Activist Sign Suggests Lynching Same-Sex Couples." AlterNet. N.p., 28 Jul 2010. <http://blogs.alternet.org/speakeasy/2010/07/28/disgusting-anti-gay-marriage-groupsactivist-sign-suggests-lynching-same-sex-couples/>.

Taranto, James. "Prematurely Gay." American Spectator. 45. No. 6 (2012): 60-61.

Victor, Jennifer Nicoll. 2007. "Strategic Lobbying." American Politics Research. 35. no. 6 (2007): 826-845.

Walton, Douglas N. Appeal to Popular Opinion. University Park, Pa: Pennsylvania State University Press, 1999. Wesson, Gail. 1994. "Trustee Hits Group's Prop. 187 View Boards Organization Against SOS Effort." Press-Enterprise, the (Riverside, CA), B01.

Williams, Norman R. 2012. "Why the National Popular Vote Compact is Unconstitutional." Brigham Young University Law Review. 5 (2012): 1523-1583.

Wolfinger, Raymond E., and Steven J. Rosenstone. Who votes? New Haven: Yale University Press. (1980).

Young, Anna M., Adria Battaglia, and Dana L. Cloud. "(UN)Disciplining The Scholar Activist: Policing The Boundaries Of Political Engagement." Quarterly Journal Of Speech. 96. no. 4 (2010): 427-435. 